PROCEDIA

Studi Kasus dan Intervensi Psikologi

ISSN:2302-1462

Volume 7(2) 47-54, Juli 2019

DOI: $10.22219 /$ procedia.v7i1.12980

\title{
Strategic family therapy untuk mengatasi pola komunikasi yang bermasalah
}

Dian Putriana, UniversitasMuhammadiyah Malang, Malang, Indonesia

Korespondonesi:

Dian Putriana, UniversitasMuhammadiyah Malang, Malang

Korespondonesi:

Inastasya, Universitas Muhammadiyah Malang, e-mail:diputna@gmail.com

\section{Riwayat artikel \\ Naskah diterima: \\ 10/11/2018}

Revisi diterima:

$25 / 11 / 2018$

Naskah disetujui:

12/12/2018

\begin{abstract}
Abstrak
Keadaan keluarga yang memiliki beberapa masalah, seperti kurangnya kepedulian akan kesehatan salah satu anggota keluarga, merasa tidak perlu mengungkapkan masalah yang dialami pada anggota keluarga. Hal ini secara tidak langsung membuat kehidupan keluarga menjadi kurang harmonis dan menimbulkan masalah-masalah baru yang lebih rumit. Berdasarkan hasil asesmen diketahui telah terjadi permasalahan pola komunikasi yang tidak langsung (indirect communication) di dalam keluarga. Oleh karenanya dilakukan intervensi strategic family therapy untuk memperbaiki pola komunikasi keluarga menjadi pola komunikasi langsung (direct communication). Intervensi dilakukan dalam 9 sesi, dan hasilnya adalah setiap anggota keluarga memiliki pola komunikasi yang semakin hari semakin membaik. Masalah demi masalah dapat dibahas dengan baik bersama-sama secara langsung, serta dapat mendiskusikan strategi menangani masalah keluarga secara bersama-sama pula. Hasil follow up juga memperlihatkan bahwa keadaan keluarga semakin baik dan bahagia. Komunikasi yang berlangsung di dalam keluarga juga terlihat baik dan efektif dibandingkan sebelumnya.

Kata kunci: Pola komunikasi, indirect communication, direct communication, strategic family therapy
\end{abstract}

\section{Latar Belakang}

Keluarga merupakan salah satu aspek terpenting dalam membangun kesejahteraan setiap individu. Permasalahan pada salah satu anggota keluarga dapat secara langsung maupun tidak langsung menimbulkan permasalahan pula di keluarga secara keseluruhan. Riwayat kesehatan keluarga juga dapat menjadi faktor risiko munculnya permasalahan, seperti penyakit fisik atau 
mental yang diturunkan. Oleh karenanya keluarga menjadi hal yang penting dalam menentukan baik atau tidaknya kehidupan seseorang (Cichy, Stawski, \& Almeida, 2014; Robinson, Rodgers, \& Butterworth, 2008).

Salah satu penyebab munculnya masalah dalam keluarga adalah adanya pola komunikasi yang tidak terjalin dengan baik di rumah. Komunikasi dalam keluarga menjadi salah satu faktor psikologis yang efektif untuk menentukan keadaan kesehatan mental anggota-anggota keluarga. Beberapa penelitian juga menyebutkan bahwa orientasi percakapan dalam keluarga juga dapat menjadi indikator anggota keluarga yang sehat. Hal ini dapat dilihat dari banyaknya pengekspresian perasaan maupun ide-ide yang ditunjukkan setiap anggota keluarga apabila saling berhadapan satu sama lain (Zarnaghash \& Zarnaghash, 2013).

Permasalahan komunikasi dapat pula terjadi ketika anggota keluarga hanya berfokus pada diri sendiri tanpa mempertimbangkan perspektif anggota keluarga yang lain. Sehingga terjadi kegagalan dalam berempati antar satu sama lain dalam sebuah keluarga. Permasalahan seperti ini lah yang nantinya memunculkan bibit-bibit permasalahan baru dan lebih kompleks terjadi di dalam keluarga. Oleh karena itu setiap anggota keluarga memerlukan pengetahuan terkait cara beradaptasi dengan anggota keluarga lain agar dinamika hubungan keluarganya dapat terlihat baik (Goldberg, 2017).

Kesalahan komunikasi dan permasalahan dalam keluarga juga sering muncul ketika adanya kesenjangan di antara niat dan persepsi. Misalnya, ketika seorang anggota keluarga berkomunikasi dengan anggota keluarga lain untuk menyampaikan pesan tertentu. Namun cara penyampaian pesan itu diartikan berbeda oleh orang yang dipesani. Sehingga muncul perbedaan maksud pesan dan makna yang dirasakan, akibatkan permasalahan komunikasi dapat terjadi (Goldberg, 2017).

Masalah komunikasi yang telah dijelaskan di atas terlihat dialami oleh keluarga seorang ibu (62 tahun) yang mengalami indikasi demensia ringan. Keluarga ini terdiri dari ibu, anak bungsu, anak sulung, menantu, dan 3 cucu usia di bawah 7 tahun. Permasalahan ini berawal dari permintaan anak sulung agar ibu tinggal bersamanya di Malang setelah ibu pensiun. Kemudian anak sulung juga meminta agar ibu menjaga ke-3 anaknya setiap hari di rumah, karena ia dan istrinya bekerja satu hari penuh. Mendengar hal itu ibu menyetujui saja permintaan anak sulungnya. Walaupun sebenarnya terlihat bahwa ibu mengalami tekanan dengan rutinitasnya tersebut di rumah. Namun ibu tidak bisa mengutarakan perasaannya pada anak sulungnya. Dan justru mengakibatkan ibu sering menyakiti diri, dan memarah-marahi anak bungsunya.

Kesalahan komunikasi sering kali menyebabkan konflik dalam keluarga atau bahkan dapat memperburuk konflik yang telah ada (Goldberg, 2017). Seperti pada masalah komunikasi keluarga ibu $\mathrm{C}$ yang telah dijelaskan di atas. Ibu $\mathrm{C}$ memiliki kondisi kesehatan yang kurang baik dan sangat jenuh dengan rutinitasnya di rumah yang harus menjaga 3 cucunya. Namun ibu tidak bisa mengkomunikasikan perasaannya pada anak sulung tentang keadaannya dan apa yang ia butuhkan. Selain itu anak sulung juga tidak pernah menanyakan keadaan ibu untuk membuktikan baiknya pola komunikasi di keluarga ini. Selanjutnya, anak bungsu beberapa kali memberitahukan kakaknya tentang keadaan ibu, namun kakak tidak mempercayainya karena ia melihat ibu baik-baik saja.

Berdasarkan permasalahan tersebut maka dibutuhkan strategi intervensi untuk mengajarkan keluarga cara komunikasi yang baru dan lebih efektif. Intervensi yang dimaksud adalah strategic family therapy yang berguna untuk memecahkan masalah hubungan interpersonal di dalam keluarga dan berfokus pada masalah pola komunikasi di dalam keluarga tersebut (Szapocznik \& Williams, 2000). Intervensi ini diharapkan membuat ibu, anak sulung, maupun anak bungsu mampu mengatur dan memperbaiki pola komunikasi yang sudah ada. Sehingga diharapkan akan berimbas pada keadaan kesehatan ibu yang semakin membaik setelahnya. 


\section{Metode Asesmen}

Asesmen untuk penegakan diganosa yang tepat dilakukan melalui serangkaian metode antara lain wawancara, observasi dan skala komunikasi keluarga. Wawancara dilakukan terhadap ibu, anak sulung, dan anak bungsu untuk memperoleh informasi lebih mendalam tentang riwayat permasalahan keluarga yang dialami. Observasi dilakukan untuk pemeriksaan status mental anggota keluarga dan untuk memperoleh informasi perilaku dan aktivitas keluarga sehari-hari.

\section{Presentasi Kasus}

Berdasarkan hasil asesmen yang telah dilakukan, diketahui bahwa terdapat ibu (62 tahun), anak sulung (L/34 tahun), dan anak bungsu (P/21 tahun) yang memiliki beberapa masalah. Salah satunya adalah terkait pola komunikasi yang kurang efektif di dalam keluarga. Hal ini seperti kurang adanya keinginan untuk menceritakan masalah yang dialami ke anggota keluarga lain, dan justru melampiaskan masalah tersebut pada hal-hal lain seperti marah-marah dan menyakiti diri sendiri. Hal yang dijelaskan di atas dilakukan oleh ibu yang memiliki masalah yang cukup serius, namun kurang adanya keberanian untuk mengungkapkan. Masalah tersebut adalah perasaan jenuh berada di rumah, jenuh dengan rutinitas yang ada, dan bahkan memiliki masalah kesehatan yakni kepikunan.

Kondisi kesehatan ibu yang semakin menurun membuat tubuhnya terlihat kurus dan terdapat beberapa bagian tubuh yang memar. Hal ini terjadi akibat ibu sering menyakiti dirinya sendiri saat ia kesal dan jenuh. Namun anggota keluarga lain tidak pernah mengetahui kondisi tersebut, kecuali anak bungsu yang memiliki hubungan yang lebih dekat dengan ibu. Anak bungsu selalu menjadi tempat untuk ibu bercerita, dan bahkan anak bungsu juga lah yang menjadi sasaran ibu ketika marah karena berbagai hal. Mendapati keadaan tersebut anak bungsu pun berontak dan ingin memperbaiki masalah yang ada. Namun ketika ia memberitahukan masalah ibu pada kakaknya (anak sulung), justru kakak tidak mempercayainya dan ibu selalu mengelak perkataan anak bungsu tersebut.

Setiap harinya, anak sulung menitipkan 3 anaknya untuk dirawat ibunya di rumah sementara ia bekerja. Anak sulung merupakan seorang pria yang sangat sibuk bekerja, dan ibu telah pensiun dari pekerjaannya. Sehingga menurut anak sulung, merawat cucu adalah sebuah kegiatan yang baik untuk ibunya. Namun hal yang dirasakan ibu tidak demikian. Ibu berkata bahwa ia tidak menyukai rutinitasnya di rumah, seperti menjaga cucu atau diam saja di rumah tanpa memiliki kegiatan di luar. Namun ibu tidak memiliki keberanian untuk mengatakan hal tersebut pada anak sulungnya, dan ibu tetap saja mengikuti perintah anaknya tersebut. Walaupun ibu menyadari bahwa rutinitasnya di rumah lah yang menjadi sumber masalah di dalam dirinya. Dan anak sulung tidak pernah mengetahui hal itu atau sekedar basa-basi menanyakan tentang masalah ibunya tersebut.

Keadaan keluarga yang seperti ini telah terjadi selama kurang lebih 3 tahun sejak ibu, anak sulung, dan anak bungsu tinggal bersama di satu rumah. Kurang adanya kedekatan antara anggota keluarga satu sama lain, dan kurang adanya kepekaan untuk melihat suatu masalah telah terjadi di dalam keluarga. Hal ini menjadi alasan kuat untuk meningkatnya masalah di dalam sistem keluarga. Masalah yang dimaksud adalah terkait pola komunikasi tidak langsung yang biasa dilakukan oleh masing-masing anggota keluarga. Seperti ibu yang tidak ingin menceritakan masalahnya pada anak sulungnya dan justru mengungkapkannya dengan marah dan menyakiti dirinya sendiri; serta anak sulung yang tidak memiliki keinginan untuk berbincang-bincang dengan ibunya. Hal ini dilakukan dengan alasan ia sibuk bekerja; dan anak bungsu yang selalu menjadi sasaran amarah ibunya karena kejenuhan dan kekesalan ibu terhadap masalahnya.

Anak bungsu yang sering menjadi sasaran kemarahan ibu juga memiliki kondisi psikologis yang kurang baik. Ia merasa dirinya selalu salah di mata ibu dan ia juga kesal dengan dirinya 
sendiri karena tidak mampu merawat ibu dengan baik. Selain itu anak bungsu juga mengaku bahwa komunikasinya dengan kakak juga bermasalah sejak mereka kecil. Kakak tidak pernah mengajaknya mengobrol, dan ia pun tidak berani memulai pembicaraan terlebih dahulu. Pada hasil wawancara anak sulung, ia mengatakan bahwa ia yakin ibunya baik-baik saja. Hanya saja adiknya yang terlalu berlebihan menganggap ibu memiliki masalah psikologis yang perlu ditangani.

Dinamika psikologis permasalahan keluarga ini dapat dijelaskan melalui konsep indirect communication anggota keluarga terbiasa mengungkapkan perasaannya secara tidak langsung atau berupa perilaku nonverbal. Hal ini dilakukan agar menghindari konflik, ketegangan, dan situasi yang tidak nyaman. Sementara itu komunikasi tidak langsung seperti ini mengakibatkan umpan balik yang terlambat dan cenderung menghasilkan permasalahan baru di dalam keluarga (Joyce, 2012). Hal ini dilakukan oleh ibu pada anak sulungnya, dimana ketika ibu jenuh dengan rutinitasnya yang mengharuskan dirinya merawat 3 cucunya di rumah. Ibu justru sering menunjukkan perasaannya dengan hanya melamun, marah-marah tak beralasan pada anak bungsu, dan menyakiti dirinya sendiri. Hal ini dilakukan karena ibu tidak ingin anak sulungnya mengetahui bahwa ia tidak suka dengan rutinitasnya di rumah.

Oleh karenanya dibutuhkan suatu solusi untuk mengakhiri pola permasalahan indirect communication tersebut. Solusi yang diperlukan dapat dibantu dengan terapi keluarga yang dapat menstimulasi setiap anggota keluarga untuk menjabarkan permasalahan yang terjadi di dalam keluarganya. Setelah itu keluarga dapat mengambil langkah untuk mengakhiri permasalahan tersebut bersama-sama. Sehingga secara tidak langsung keluarga akan dibiasakan untuk memiliki pola komunikasi yang langsung atau direct communication.

\section{Diagnosis dan Prognosis}

Berdasarkan kesesuaian antara kriteria teori komunikasi keluarga dapat didiagnosa bahwa keluarga Subjek mengalami permasalahan pola komunikasi tidak langsung (indirect communication). Prognosis baik karena anggota keluarga memiliki keinginan untuk memperbaiki keadaan keluarganya yang bermasalah.

\section{Intervensi}

Berdasarkan hasil asesmen yang telah dilakukan, terapis menyarankan strategic family therapy sebagai upaya memperbaiki pola komunikasi yang bermasalah di keluarga ibu. Intervensi strategic family therapy ini terbukti efektif untuk memperbaiki pola komunikasi yang bermasalah menurut penelitian yang telah dilakukan oleh Utami (2017). Pada terapi ini diharapkan anggota keluarga dapat menemukan solusi terbaik untuk menyelesaikan masalah yang terjadi. Terapi ini dilakukan dengan cara mengumpulkan seluruh anggota keluarga yang terkait dengan masalah utama, kemudian seluruh anggota keluarga bersama-sama mendiskusikan pemecahan masalah untuk keluarganya (Szapocznik \& Williams, 2000).

Strategic family therapy berasumsi bahwa setiap keluarga memiliki karakteristik unik dan hanya terlihat jelas ketika anggota keluarga berinteraksi. Sistem keluarga ini memengaruhi seluruh anggota keluarga. Oleh karenanya di dalam strategic family therapy, keluarga dianggap sebagai bagian atau sistem yang saling bergantung atau terkait. Perilaku satu anggota keluarga dapat memengaruhi keadaan sistem keluarga itu sendiri. Terlebih ketika terjadi masalah komunikasi, maka permasalahan keluarga yang lebih kompleks akan terjadi (Szapocznik \& Williams, 2000).

Pada permasalahan keluarga Subjek, komunikasi yang terjadi di dalam keluarga termasuk bermasalah. Permasalahan tersebut terjadi akibat ibu yang memiliki kejenuhan akan rutinitasnya dan ia tidak dapat mengomunikasikan dengan baik perihal perasaannya pada anak sulungnya. Sementara itu anak sulung juga tidak terbiasa berkomunikasi secara langsung 
pada ibu untuk sekedar menanyakan keadaan kesehatan maupun perasaan ibu setiap harinya. Selanjutnya anak bungsu yang juga bertempat tinggal di rumah yang sama memiliki tekanan juga akibat perilaku ibu yang selalu melampiaskan emosi padanya. Sehingga anak bungsu berinisiatif untuk mengomunikasikan keadaan ibu pada kakaknya, namun kakaknya tidak mempercayai karena ibu terlihat tidak pernah mengeluh padanya.

Pada terapi ini, anggota-anggota keluarga diminta untuk berkumpul dan saling berbicara dengan berfokus pada masalah dan solusi yang direncanakan. Pertama-tama keluarga diminta untuk memfokuskan masalah terlebih dahulu, kemudian menentukan apa yang menjadi target untuk menyelesaikan masalah tersebut. Setelah itu anggota keluarga dan terapis bersama-sama menetapkan rencana untuk membantu keluarga mengembangkan pola komunikasi yang lebih efektif (Goldberg, 2017).

Lebih jelasnya, adapun beberapa sesi yang diberikan pada intervensi strategic family therapy menurut Goldenberg \& Goldenberg (2008) adalah sebagai berikut:

Sesi 1. Mengomunikasikan desain program.Pada sesi ini terapis menjelaskan secara singkat terkait desain program yang telah dirancang untuk dilakukan. Terapis menjelaskan terkait strategic family therapy yang tujuannya untuk membentuk sebuah strategi yang lebih efektif dalam menangani masalah keluarga. Dan untuk keberhasilannya diperlukan proses diskusi antara setiap anggota satu sama lain untuk memecahkan strategi tersebut bersama-sama.

Sesi 2. Social stage dan problem stage. Pada sesi ini terapis menghadirkan seluruh anggota keluarga untuk berpendapat tentang masalah yang terjadi, dan menjelaskan alasan mengapa mereka perlu hadir, serta pengisian pre-test. Di sesi ini hasil yang didapat adalah Anak sulung tidak merasa memiliki masalah yang berarti di dalam keluarganya, sementara ibu masih diam dan mengatakan ia baik-baik saja, dan anak bungsu yang menceritakan masalah ibunya yang sebenarnya dan beberapa kekesalannya.

Sesi 3. the Interaction stage. Pada sesi ini terapis meminta komentar dari setiap anggota keluarga yang hadir dan membicarakan masalahnya bersama-sama. Di sesi ini pula tejadi adu pendapat dan saling membantah antara satu sama lain terkait masalah yang terjadi. Namun akhirnya dapat disimpulkan bahwa inti dari masalah adalah antara ibu yang jenuh dengan rutinitasnya di rumah dan anak sulung yang tidak pernah menanyakan keadaan ibu.

Sesi 4. Defining desired changes. Pada sesi ini terapis menanyakan perubahan seperti apa yang diharapkan setelah semua anggota keluarga mengetahui permasalahan yang terjadi. Hingga akhirnya ditemukan bahwa seluruh peserta intervensi mengharapkan keadaan ibu semakin membaik dan ibu tidak lagi menyakiti dirinya sendiri karena kekesalan dan kejenuhannya.

Sesi 5. Ending the interview. Pada sesi ini terapis mengarahkan peserta intervensi untuk berdiskusi terkait langkah yang diambil setelah dicapai kesepakatan bersama mengenai definisi masalah. Di sesi ini pula antara anak bungsu dan anak sulung bersama-sama bertukar pikiran terkait hal yang terbaik untuk ibu mereka. Hingga akhirnya ditentukan bahwa ibu harus memiliki kegiatan di luar rumah, seperti mengikuti arisan komplek atau pengajian. Selain itu anak sulung dan anak bungsu juga memiliki perjanjian untuk lebih perhatian pada ibu dan rutin menanyakan kabar ibu setiap harinya.

Sesi 6. Directive. Pada sesi ini terapis membimbing peserta intervensi untuk menciptakan perilaku yang berbeda dari sebelum intervensi, sehingga memperoleh pengalaman subjektif yang berbeda. Di sesi ini pula peserta intervensi diberikan penugasan untuk melakukan hal-hal yang sesuai dengan hasil diskusi sebelumnya.

Sesi 7. Evaluasi. Pada sesi ini terapis menemukan perubahan perilaku yang positif terhadap keadaan keluarga. Pola komunikasi pun perlahan-lahan berjalan secara langsung dan efektif, sehingga masalah-masalah inti dapat terselesaikan dengan baik. 
Sesi 8. Follow up. Pada sesi ini terapis melihat perubahan pola komunikasi keluarga setelah 2 minggu pasca intervensi. Dan ditemukan bahwa semakin hari pola komunikasi keluarga tersebut semakin baik, dan keadaan keluarga menjadi lebih baik dari sebelumnya.

Sesi 9. Terminasi. Sesi terminasi dilakkan untuk menutup jalannya intervensi.

\section{Hasil dan Pembahasan}

\section{Hasil}

Hasil intervensi dapat dilihat berdasarkan kesesuaian antara target dan realita selama jalannya intervensi. Seluruh anggota keluarga dapat mengikuti intervensi dengan baik, sehingga target terapi dapat tercapai. Masalah utama di dalam keluarga juga telah diidentifikasi bersama-sama yakni pola komunikasi yang tidak langsung atau indirect communication antara anggota keluarga satu dengan yang lain.

Di dalam proses jalannya intervensi (hasil diskusi) didapatkan beberapa masalah yang merupakan yang terjadi di dalam keluarga ini. Di antaranya adalah terbatasnya ruang gerak ibu yang setiap hari harus terus berada di rumah untuk menjaga cucunya. Sehingga ibu tidak bisa beraktivitas seperti saat dulu sebelum ibu tinggal bersama anak sulungnya. Selanjutnya perasaan jenuh ibu disadari mulai terjadi, sehingga menjadikan hal tersebut sebagai beban pikiran. Beban pikiran itu lah yang mengakibatkan ibu menjadi mudah lupa, sering melamun, dan sering menyakiti dirinya sendiri. Serta anak sulung juga menyadari bahwa hal tersebut terjadi akibat dirinya yang sama sekali tidak mengetahui atau bahkan tidak menanyakan keadaan ibu setiap harinya. Hingga akhirnya memberlakukan pola komunikasi yang langsung atau direct di dalam keluarga diketahui dapat mengurangi masalah-masalah yang terjadi tersebut.

Berdasarkan hasil evaluasi yang dilakukan menggunakan self-report dan skala komunikasi keluarga, ditemukan bahwa terjadi peningkatan pola komunikasi yang semakin baik (direct) setelah dilakukan intervensi. Hasil self-report juga menunjukkan bahwa solusi-solusi yang telah dibicarakan sebelumnya telah dilakukan dengan baik sesuai dengan waktu yang disepakati. Secara ringkas, keadaan subjek sebelum intervensi menunjukkan kurang adanya komunikasi secara langsung antara masing-masing anggota keluarga. Sehingga terdapat anggota keluarga yang tidak mengetahui masalah yang terjadi antara satu sama lain. Hal yang dimaksud adalah terkait kondisi kejenuhan ibu akan rutinitasnya di rumah, masalah kepikunan ibu, dan ibu yang sering menyakiti diri sendiri. Namun anak sulung tidak pernah mengetahuinya karena ibu tidak pernah bercerita, dan ia pun tidak pernah bertanya. Sehingga justru ibu mengekspresikan masalah-masalahnya tersebut dengan marah-marah pada anak bungsu dan menyakiti dirinya sendiri. Setelah intervensi dilakukan, keluarga mulai menerapkan pola komunikasi langsung atau direct, sehingga permasalahan yang dialami keluarga mulai berkurang. Hal tersebut ditandai dengan setiap anggota keluarga yang telah mengetahui masalah masing-masing anggota keluarga dan apa yang mereka rasakan. Keluarga pun memiliki komitmen untuk menerapkan perilaku baru yang lebih baik demi membaiknya kondisi ibu. Anggota keluarga juga dapat menentukan strategi-strategi yang tepat dan harus mereka lakukan untuk memperbaiki masalah komunikasi keluarga mereka.

\section{Pembahasan}

Berdasarkan hasil intervensi yang telah dilakukan, dapat diketahui bahwa strategic family therapy dapat memperbaiki pola komunikasi yang bermasalah di dalam keluarga. Hal ini sesuai dengan fokus dari strategic family therapy yang mengacu pada pola komunikasi sebagai aspek terpenting dalam terbentuknya masalah. Sehingga strategic family therapy mengutamakan memperbaiki komunikasi antar keluarga terlebih dahulu agar masalah-masalah yang mengikuti dapat perlahan membaik (Rambo, Rhoades, Boyd, \& Bello, 2014; Rhoades, 2014). 
Strategic family therapy meyakini bahwa perubahan pola komunikasi dapat saja cepat terjadi ketika anggota keluarga dapat menerapkan strategi yang spesifik. Strategi spesifik tersebut lah yang digunakan untuk memperbaiki perilaku berulang di dalam keluarga. Perilaku berulang yang dimaksud adalah perilaku bermasalah yang merupakan akibat dari pola komunikasi. Sehingga seluruh anggota keluarga didorong untuk mencari strategi atau solusi terbaik dalam memperbaiki pola komunikasi keluarga dan perilaku berulang yang dimaksud (Klajs, 2016).

Pola komunikasi yang baik dapat tercapai apabila kedua dimensi mendasar dari komunikasi antar keluarga juga berjalan dengan baik. Dua dimensi tersebut yakni orientasi percakapan dan orientasi kesesuaian. Orientasi percakapan merupakan sejauh mana keluarga menciptakan iklim dimana semua anggota keluarga didorong untuk mau berpartisipasi dalam interaksi setiap saat tentang beragam topik. Sedangkan orientasi kesesuaian mengacu pada sejauh mana komunikasi keluarga menekankan iklim homogenitas sikap, nilai, dan keyakinan. Sehingga ketika pola komunikasi sebuah keluarga baik, maka anggota keluarganya dapat dikatakan memiliki interaksi yang baik satu sama lain, serta memiliki nilai-nilai yang sesuai dengan anggota keluarga lain (Koerner \& Fitzpatrick, 2002).

Maksud dasar dari intervensi ini adalah untuk mendorong sistem keluarga mencapai sebuah pemikiran strategis sehingga masalah atau gejala yang ditimbulkan tidak lagi mengganggu fungsi keluarga. Perubahan ini terjadi bukan melalui wawasan dan pemahaman, melainkan melalui proses keluarga melaksanakan arahan yang dikeluarkan oleh terapis. Hal ini terjadi dengan baik saat jalannya intervensi, dimana keluarga mengikuti setiap arahan terapis hingga menghasilkan strategi atau solusi-solusi terbaik guna memperbaiki kondisi keluarga yang bermasalah (Goldenberg \& Goldenberg, 2008).

\section{Simpulan}

Berdasarkan hasil intervensi yang telah dilakukan, seluruh anggota keluarga dapat mengikuti jalannya intervensi dengan baik. Strategi atau solusi yang diharapkan tercapai untuk menangani masalah pun dapat dimunculkan setelah intervensi berakhir. Selanjutnya target utama intervensi yakni pola komunikasi langsung (direct communication) juga telah tercapai pasca intervensi. Perilaku-perilaku yang menunjukkan membaiknya pola komunikasi mulai terlihat di dalam keluarga, sehingga masalah ibu seperti sering melamun dan menyakiti diri sendiri semakin tidak terlihat.

Bagi keluarga yang memiliki anggota keluarga seorang lansia, diharapkan lebih memiliki sikap peduli akan kesehatan dan psikologis anggota keluarga tersebut. Sikap kepedulian tersebut cukup dengan menanyakan keadaan atau kabar yang bersangkutan setiap hari, atau sekedar mengobservasi kegiatan kesehariannya. Sehingga meminimalisir keadaan yang semakin buruk dari anggota keluarga lansia tersebut.

\section{Referensi}

Barnes, H. L., \& Olson, D. H. (1982). Parent-adolescent com- munication scale. In Family inventories: Inventories used in a national survey of fami- lies across the family life cycle (pp. 51-63). Minnesota: University of Minnesota.

Cichy, K. E., Stawski, R. S., \& Almeida, D. M. (2014). A double-edged sword: Race, daily family support exchanges, and daily well-being. Journal of Family Issues, 35(13), 1824-1845. https://doi.org/10.1177/0192513X13479595

Goldberg, C. R. M. (2017). Communication errors/problems in couples. In The SAGE Encyclopedia of Marriage, Family, and Couples Counseling (pp. 300-302). Thousand Oaks: SAGE Publications, Inc. Retrieved from www.sagepub.com

Goldenberg, H., \& Goldenberg, I. (2008). Family therapy: An overview. (Meaghan Banks, Ed.) (Seventh). USA: Thomson Brooks/Cole.

Joyce, B. C. (2012, November). The impact of direct and indirect communication. The International Ombudsman Association, pp. 1-4.

Klajs, K. (2016). Jay Haley - Pioneer in strategic family therapy. Psychoterapia, 2(177), 17-28. 
Koerner, A. F., \& Fitzpatrick, M. A. (2002). Understanding family communication patterns and family functioning: The roles of conversation orientation and conformity orientation. In Communication Yearbook (pp. 36-68). Minneapolis: Department of Communication Studies. https://doi.org/10.1080/23808985.2002.11679010

Kraemer, S. (2002). Systemic and family therapeutic approaches in psychiatry. In Therapeutic Approaches (pp. 21-24). The Medicine Publishing Company Ltd.

Rambo, A. H., Rhoades, E. A., Boyd, T. V, \& Bello, N. (2014). Introduction to systemic family therapy. In Auditory-Verbal Practice (pp. 113-135).

Rhoades, E. A. (2014). Core constructs of family therapy. In Auditory-Verbal Practice (pp. 136-163).

Robinson, E., Rodgers, B., \& Butterworth, P. (2008). Family relationships and mental illness. AFRC Issues Australian Family Relationships Clearinghouse, 1(4), 1-19. Retrieved from www.aifs.gov.au\%0AEdited

Szapocznik, J., \& Williams, R. A. (2000). Brief strategic family therapy: Twenty-five years of interplay among theory, research and practice in adolescent behavior problems and drug abuse. Clinical Child and Family Psychology Review, 3(2), 1-20.

Utami, W. (2017). Strategic family therapy untuk memperbaiki komunikasi dalam keluarga di Nganjuk. Journal An-Nafs, 2(2), 140-153.

Zarnaghash, M., \& Zarnaghash, N. (2013). The relationship between family communication patterns and mental health. Procedia - Social and Behavioral Sciences, 84, 405-410. https://doi.org/10.1016/j.sbspro.2013.06.575 